\title{
Sappho's Brothers Song and the Fictionality of Early Greek Lyric Poetry
}

\author{
André Lardinois
}

It is a good time to be working on Sappho. ${ }^{1}$ Twelve years ago two new poems were published, including the so-called Tithonos poem, in which Sappho (or better: the I-person) complains about the onset of old age. ${ }^{2}$ The number of publications devoted to this poem was starting to dry up, when suddenly a new set of papyri was discovered in 2014. One might be forgiven for suspecting that a creative papyrologist was behind these finds, but it looks like the papyri are genuine and that we owe them to the gods and to the enduring popularity of Sappho's poetry in antiquity.

The new discovery consists of five papyrus fragments, preserving the remains of no less than nine poems of Sappho. ${ }^{3}$ Among these are five complete stanzas of a previously unknown song, which Obbink has labelled 'Brothers Poem' or 'Brothers Song.' ${ }^{4}$ This article deals mainly with this poem, preserved on P. Sapph. Obbink and re-edited by Obbink in the opening chapter of this volume. The argument consists of four parts. First I will say something about the authenticity of the Brothers Song. Next I will discuss what we know about Sappho's brothers from the ancient biographical tradition and other fragments of Sappho. Then I will discuss the content of the Brothers Song in more detail and, finally, I will present my interpretation of the song.

1 Oral versions of this paper were delivered at the universities of Amsterdam, Basel, Groningen, Leiden, Nijmegen and Oxford. I would like to thank the different audiences, as well as Toni Bierl, Vanessa Cazzato, Joel Lidov and Dirk Obbink, for their comments and suggestions. An earlier written version was published in Dutch (Lardinois [2014]), but I have changed my mind on several issues concerning the Brothers Song since then.

2 Gronewald and Daniel (2004a), (2004b) and (2007). For detailed discussions of this poem, see Buzzi and Aloni (2008), and Greene and Skinner (2009).

3 See Obbink, ch. 1, this volume.

4 Obbink (2014b) and ch. 1, this volume.

(C) ANDRÉ LARDINOIS, 2016 | DOI: 10.1163/9789004314832_009

This is an open access chapter distributed under the terms of the Creative Commons Attribution-

Noncommercial 3.o Unported (CC-BY-NC 3.0) License. 


\section{Authenticity}

The papyrus on which the Brothers Song was written has been subjected to $\mathrm{C} 14$ analysis. This analysis dates it roughly to a period between the first and third century $\mathrm{CE}$, a dating which agrees with the hand in which the text was written. The ink with which the text was written has been examined further through light spectrum analysis. ${ }^{5}$ All indications are that the text dates from antiquity. This dating does not guarantee that the poem is authentic, since it leaves open the possibility that it is an ancient forgery. Both the biographical content of the poem and the old Lesbian dialect fit the literary taste of the time in which the papyrus was written, a period known in Greek literature as the Second Sophistic. However, the Brothers Song was found together with the fragments on P. GC Inv. 105, which derive from the first book of a Hellenistic edition of poems of Sappho. ${ }^{6}$ That the Brothers Song was included in at least one other contemporary edition has been demonstrated convincingly by Simon Burris, who identified a very small fragment from the Oxyrhynchus papyri that overlaps with the text of this song. This is P. Oxy 2289 fragment 5 , which is so small that it is not even included in Voigt's edition of Sappho's fragments. ${ }^{7}$ The Brothers Song is therefore not an entirely new poem: we already possessed a tiny fragment of it. This fragment not only overlaps with letters at the beginning of the first strophe of the new Brothers song, but it also preserves five letters from the last two lines of the strophe that preceded the five preserved strophes on the new papyrus. Obbink has now rightly added these to his text of the song. ${ }^{8}$

Hellenistic scholars therefore already recognized the Brothers Song as being by Sappho and included it in at least some of their editions. That still allows for the possibility that it was an imitation of a Sapphic poem made in the fifth or fourth century BCE, but this is true of almost any fragment we have of Sappho. These fragments are derived from poems which the Hellenistic scholars thought Sappho had composed. It is not impossible that there were among these poems songs that were composed by other, anonymous Lesbian poets, fifth- or fourth-century imitations, and distorted versions of Sappho's original poems. In this case, however, we have a fifth-century witness, Herodotus, who informs us that Sappho composed a melic song about her brother Charaxos. This shows that by the end of the fifth century вСЕ songs about Charaxos were

5 Obbink (2014a) and, ch. 2, this volume.

6 P. GC. Inv. 105 frs. 1-4: see Burris, Fish and Obbink (2014) and Obbink, ch. 1, this volume.

7 It is printed in Lobel \& Page (1955) 11.

8 Obbink (2015a) and ch. 1, this volume. 
circulating in the Greek world and were attributed to Sappho. I therefore see little reason to doubt that this song goes back to Sappho or at least to sixthcentury BCE Lesbos, based on what we know about it today.

\title{
The Biographical Tradition
}

Sappho's brothers were already known to us from the biographical tradition attached to her in antiquity. An example is this short biography, dating back to the Hellenistic period and preserved on P. Oxy 1800:

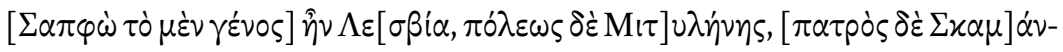

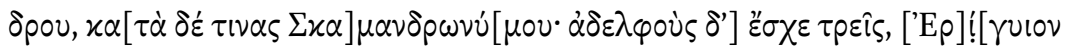

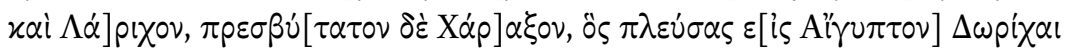

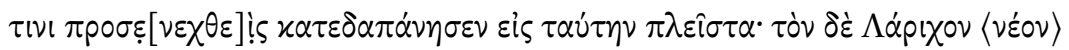

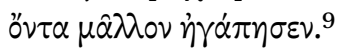

Sappho was a Lesbian by birth, from the city of Mytilene, her father was Skamandros or according to others Skamandronymos. She had three brothers: Erigyios and Larichos, and Charaxos, the oldest, who sailed to Egypt and, having met a certain Doricha, spent a great deal of money on her. She [= Sappho] was more fond of young Larichos.

Other ancient sources provide us with similar information..$^{10}$ Herodotus discusses Charaxos' affair with a courtesan, whom he calls Rhodopis and who is really his main interest. In Book 2 of his Histories he devotes two paragraphs to her (Hdt. 2.134-135), the second one of which begins as follows:

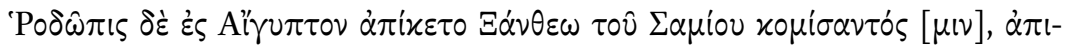

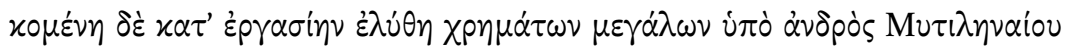

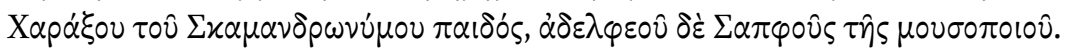

Rhodopis came to Egypt having been brought there by Xanthos the Samian, and having been put to work, she was freed for a large sum of money by a man from Mytilene, Charaxos, the son of Skamandronymos and the brother of Sappho the poet.

9 Test. $25^{2}$ (P. Oxy. 1800 fr. 1).

10 Test. 253 (the Suda), test. 213A h (P. Oxy. 2506 fr. 48, col. Iii, vv. 36-48). 
There follows a short paragraph in which Herodotus tells us more about Rhodopis. He then closes the paragraph with the following sentence: Xáp $\alpha \xi \circ \varsigma \delta \dot{\varepsilon} \omega \varsigma$

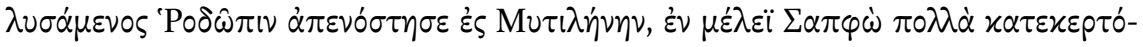
$\mu \eta \sigma \varepsilon \dot{\varepsilon} \mu \nu$. ('When Charaxos returned to Mytilene, after he had freed Rhodopis, Sappho greatly [or repeatedly] criticized him in a song')

Because the personal pronoun $\mu \nu v$ can refer to a woman as well as a man, it has been argued that Herodotus in this sentence is not saying that Sappho criticized him (Charaxos), but her (Doricha). ${ }^{11}$ The word order of the sentence, however, strongly favours a reference to Charaxos. Charaxos' name is prominently placed as topic at the front of the whole sentence, outside the subordinate clause to which it syntactically belongs. In other sentences in Herodotus which are structured in this way, such a topic always returns in the main clause either as subject or object. ${ }^{12}$ One expects the same here. Ovid too seems to have understood Sappho's poetry (or Herodotus' account) in this way, since he makes Sappho say in his Heroides that she often gave her brother good advice, while using a certain 'freedom' (libertas) of speech..$^{13}$ This libertas reads like a euphemism put by Ovid in the mouth of Sappho for the 'vehement criticism' Herodotus ascribes to her. ${ }^{14}$ I therefore hold to the standard interpretation of this sentence, according to which Sappho criticized her brother Charaxos. ${ }^{15}$ Later authors, such as Strabo and Athenaeus, identified Herodotus' Rhodopis with Doricha, whose name, unlike Rhodopis', they apparently did find in Sappho's poetry. ${ }^{16}$

We read more about her brother Larichos in Sappho testimonium 203. This testimonium contains two passages about Larichos. The first is a passage from Athenaeus: "The lovely Sappho often praises her brother Larichos, because he poured the wine in the townhall for the Mytileneaeans' $\left(\sum \alpha \pi \varphi \omega^{\prime} \tau \varepsilon \dot{\eta} x \alpha \lambda \dot{\eta} \pi \circ \lambda \lambda \alpha-\right.$

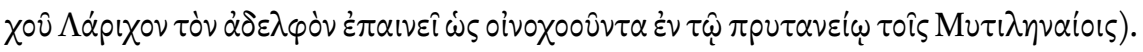

\footnotetext{
11 Ferrari (2014) 10 with earlier references. Add Bowie, this volume.

12 Hdt. 1.10.1, 1.34.3, 1.45.3, 1.48.1, 1.50.3, 1.74.3, 1.76.1, 1.83.1, 1.85.4, 1.114.4, etc. I owe these references to Helma Dik, and would like to thank her and Rutger Allan with whom I discussed this passage.

13 Ovid, Her. 15.67-68 (= test. 16 Campbell). Ovid's authorship of this poem has been disputed: see Morgan in this volume.

14 See Martin, this volume.

15 It should be noted, however, that no such 'strong criticism' of Charaxos is found in the surviving fragments of Sappho, including the new Brothers song, with the possible exception of fragment 15 (see below).

16 Strabo 17.1.33 and Athenaeus 13.596c. Doricha's name perhaps appears in fragments 7.1, 9.17 and 15.11: see below. Posidippus (Ep. 122 Austin \& Bastianini) confirms that Sappho composed a song about Doricha.
} 
A scholion to the Iliad adds to this: 'For it was custom, as Sappho also says,

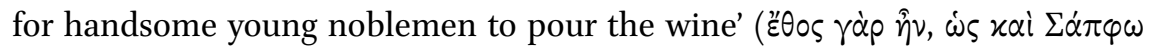

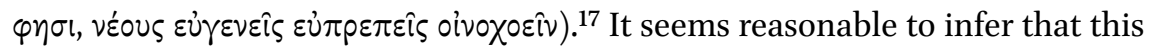
reported remark of Sappho's related to her brother Larichos pouring the wine in the townhall of Mytilene.

Several of the earlier known fragments of Sappho have already been connected to the biographical stories about her and her brothers. There is, first of all, fragment 5 , the first poem of Sappho that Grenfell and Hunt discovered at Oxyrhynchus. ${ }^{18}$ More of this song now can be restored thanks to the new

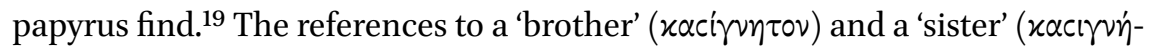
$\tau \alpha \nu)$, conjectured by Blass, have now been confirmed. The names of the brother and sister do not appear in the fragment, but Burris, Fish and Obbink observe that line 6 contains a wordplay on Charaxos' name: the brother is asked to be a

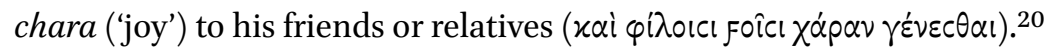

In line 18 of fragment 5 the goddess Aphrodite is invoked. She is similarly addressed in fragment 15, which also probably deals with Charaxos. The only part of this fragment that is more or less readable is the last stanza. It has been restored in Campbell (1982a) as follows:

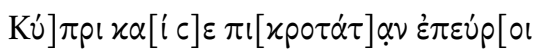

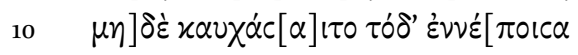

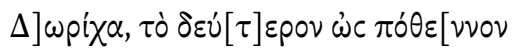

$$
\begin{aligned}
& \varepsilon i c] \text { हैpov } \hat{\eta} \lambda \theta \varepsilon \text {. }
\end{aligned}
$$

Cypris, and may he (or she) find you most bitter and may Doricha not boast, telling this how for a second time he (or she) came to a love full of longing.

The appearance of the name of Doricha in this stanza is not entirely certain and the omega should in fact be dotted, as in Voigt. According to Joel Lidov the traces of the letter do not agree with an omega, ${ }^{21}$ but Dimitrios Yatro-

\footnotetext{
17 Ath. 10.425a; Schol. т Il. 20.234 (v 41 Erbse). Cf. Eust. Il. 1205.17 ff. (= Sappho test. 203b):

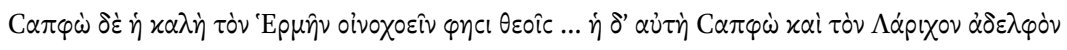

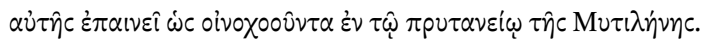

18 Grenfell \& Hunt (1898).

19 For the newly reconstructed text of this poem, see Obbink, ch. 1, this volume.

20 Burris, Fish \& Obbink (2014) 24.

$21 \quad \operatorname{Lidov}(2002) 203$.
} 
manolakis reports that: 'so little is preserved from the letter before pi $x \alpha$ in line 11 $(\Delta] \omega p^{\prime}(\chi \alpha)$ — and the position of the dot of ink preserved is so ambiguous - that it would be quite difficult to maintain that it is incompatible with an omega. ${ }^{22}$ I tend to agree with Yatromanolakis and therefore consider it not unlikely that Doricha's name stood here.

Doricha is the subject of the second clause ('may Doricha not boast ...'), but probably not of the following subclause: it makes more sense that she would boast that her lover, whom the ancient commentators identified with Charaxos, came to her love than the other way around. In that case Charaxos is probably the subject of the first clause of the stanza as well: the speaker wishes that he find the goddess of love bitter and that he not go back to Doricha. ${ }^{23}$ This stanza could then be part of the song in which Sappho 'heavily criticized' her brother Charaxos for his relationship with Doricha, as Herodotus reports, but other readings of this stanza are also possible. ${ }^{24}$

Other fragments that could possibly, though not necessarily, be connected with the story about Charaxos and Doricha are fragments 3, 7, 9 and 2o. In fragment 3.4-5 the first person speaks about someone 'hurting' her ( $\lambda \dot{u} \pi \eta c \tau \varepsilon$

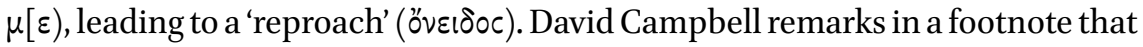
these lines are possibly addressed to Charaxos. ${ }^{25}$ It is, however, equally possible that they are addressed to a beloved. In fragment 7 the name Doricha has been restored in line 1, although only the letters - $\chi \alpha c$ are, more or less, readable. A possible reference to her dealings with Charaxos is, however, contained in line 4, where someone may be said to have 'to pay the price for arrogance'

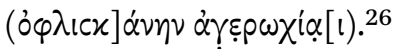

The newly reconstructed fragment 9 is more promising in this regard. Before the discovery of the new papyrus traces of only nine lines of this song were known from P. Oxy 2289. To these lines the new fragments add significant new readings as well as the remains of eleven more lines. Burris, Fish and Obbink point out that Doricha's name may have stood in line 17, although they admit that a word like $\tau] \underline{y} \chi \alpha \nu$ could equally have stood here. ${ }^{27}$ There are further indications, however, that this fragment may have had something to do with the story of Charaxos and Doricha. The sentence starting in line 8 has a

\footnotetext{
22 Yatromanolakis (2007) 331.

23 Compare Ferrari (2010) 159, who translates: 'Cypris, and may he find you [more bitter] / nor Doricha ever boast, say[ing] that for the second time he came back long[ed for]'

24 See Lidov, ch. 3, this volume.

25 Campbell (1982a) 59.

26 Ferrari (2010) 159 and (2014) 10.

27 Burris, Fish and Obbink (2014) 16. West (2014) 8 proposes $\mu \varepsilon \lambda \lambda]$ ! $\chi \alpha$.
} 


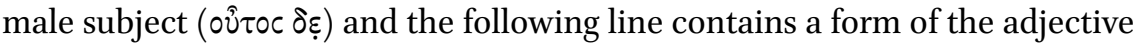
$\dot{\alpha} \beta \lambda \dot{\alpha} \beta \eta c$ with a metrically short ending: either $\ddot{\alpha} \beta \lambda \alpha[\beta \varepsilon c$ or $\dot{\alpha} \beta \lambda \dot{\alpha}[\beta \varepsilon c$, followed by a vowel. This word is reminiscent of $\alpha \beta \lambda \dot{\alpha} \beta \eta \nu$ ('unharmed') in the opening line of fragment 5 . In line 19 we read the verb 'you owe' ( $\partial \varphi \dot{\varepsilon} \lambda \lambda \eta \bar{c})$ ), which could possibly apply to Charaxos. Martin West restores the first eight lines of the fragment as a conversation between Sappho and her mother, ${ }^{28}$ but a prayer to Hera as 'mother' whose 'festival' (line 3) has to be celebrated, is possible as well (cf. fr. 17). In either case a complaint about Charaxos or a wish for his safe return may have been part of this song. ${ }^{29}$

According to the new arrangement of P. GC Inv. 105 and P. Sapph. Obbink, as proposed by West (2014) and accepted now by Obbink (ch. 2, this volume), this fragment stood between fragments 5 and the Brothers Song, both dealing with Charaxos. It may be that under the letter groupings in the Hellenistic edition of Sappho's poetry from which these fragments are derived, the editors deliberately placed the songs that they believed to be dealing with her brothers together. ${ }^{30}$ This would be another argument in favour of fragment 9 dealing with the story of Charaxos and Doricha. It also would mean that the Hellenistic editors did not consider fr. 17, which started with $\Pi$ - but was not placed with the other brothers poems starting with $\Pi$-, to be dealing with the return of Charaxos, as Caciagli argues. ${ }^{31}$

Finally there is fragment 20. In this fragment we read about a storm at sea and the loss of cargo. This could relate to one of Charaxos' sea voyages, but it could of course also be part of a different story. ${ }^{32}$ We therefore cannot say with certainty that all these fragments relate to the story about Sappho and her brothers, but it does appear that the Brothers Song was not unique. Sappho composed a number of poems about her brothers. ${ }^{33}$ Ancient biographers used these songs to reconstruct a narrative about Sappho and her brothers.

28 West (2014) 7-8.

29 See Dale (2015) 20. He connects this fragment with fragment 15.

30 See Obbink, ch. 2, this volume. Dale (2015), however, argues for a different arrangement: he connects fragment 9 with fragment 15 and places them before fragment 16 . This would still be an example of a Charaxos Song (fr. 9/15) preceding a love song (fr. 16) in the o-series, just as fr. 5 and the Brothers Song precede the Kypris Song in the ח-series.

31 Caciagli (2011) 153-155 and this volume.

32 Ferrari (2014) 12 with earlier references.

33 According to Athenaeus, Sappho 'often' ( $\pi \circ \lambda \lambda \alpha \times \circ \hat{)}$ ) praised her brother Larichos (Ath. 10.425a = Sappho test. 203a, quoted above): this suggests that she composed more than one song about him too. 


\section{Commentary}

One of the sources which the ancient biographers will undoubtedly have used to reconstruct Sappho's life is the new Brothers Song. The papyrus that contains five strophes of the song is exceptionally well preserved. Still there are a number of passages where people disagree over how to construe the Greek. I will first discuss these passages and then provide my interpretation of the poem.

In the fifth line of the newly constituted text of this song (Obbink, ch. 1) we find the aorist infinitive $\varepsilon^{2} \lambda \theta \eta v$. Ever since the first publication of the fragment, scholars have debated whether this infinitive should be translated with a past tense ('Charaxos has come') or a future tense ('Charaxos will come'). ${ }^{34}$ It is dependent on $\left.\theta p \dot{ } \lambda_{\eta}\right\rangle \in \alpha$, which means 'you babble' or 'you keep repeating'. After such a verb of speaking one would expect an infinitive construction of indirect discourse in which the aorist expresses a past tense, something like: 'you babble / you keep saying that Charaxos came with a full ship', but this translation does not fit the context. In the next sentence we read that the gods know this, but an event in the past, that Charaxos came with his ship, is something everyone could know, not only the gods.

One would therefore expect that $\varepsilon^{2} \lambda \theta_{\eta \nu}$ refers to something in the future: that Charaxos might or will come with his ship, and it has been proposed that $\varepsilon^{\prime} \lambda \theta \eta \nu$ is a dynamic infinitive, similar to the infinitive found after verbs

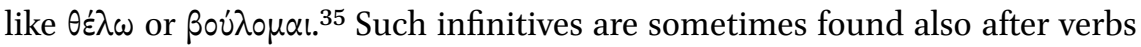
of speaking. ${ }^{36}$ An example is the following sentence in Xenophon's Anabasis:

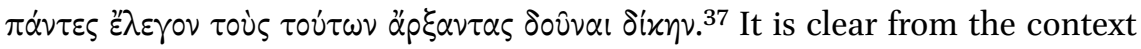
that this sentence must mean 'all said that those who started this must be punished' and not 'had been punished'. Similarly the first line of Sappho's song should read: 'but you always keep saying that Charaxos must come with his ship full'.

This construction can also be explained as a form of indirect discourse, not of a declarative sentence in the indicative, but of an original third person imperative ('let Charaxos come') or optative of wish ('may Charaxos come'). In such cases the infinitive preserves the original present or aorist aspect of the imperative or wish: in this case the aorist. According to Albert Rijksbaron, the aorist aspect in such constructions refers to a specific instance of the action described by the verb, whereas the present expresses the action of the verb in

\footnotetext{
34 E.g. Obbink (2014b) 42, West (2014) 8, Ferrari (2014) 3, Neri (2015) 57.

35 E.g. West (2014) 8.

36 Smyth (1984) 444.

37 Xen. An. 5.7.34.
} 
general. ${ }^{38}$ Here the aorist would indicate that Charaxos is at the moment of speaking at sea and expected to come home.

More recently Mark Griffith has proposed translating है $\lambda \theta_{\eta} \nu$ not with 'to have come' but with 'to have gone, departed' ${ }^{39}$ This is theoretically possible, but not very likely. Forms of the verb हैpxopal elsewhere in Sappho and Alcaeus always seem to have the meaning of 'to come' (e.g. Sappho fr. 1.5, 8, 25), and that Charaxos departed with a full ship is something that, again, not only the gods but everyone would know.

Reading $\varepsilon \lambda \theta \eta \nu$ as referring to Charaxos' coming in the future is therefore more likely. It also creates a nice opposition between the second and third strophe, and between the speaker and the addressee. The addressee always keeps babbling that Charaxos must come with a full ship. Instead he or she should be encouraging the speaker to pray to Hera repeatedly (a more helpful speech act than babbling), not that Charaxos come with a full ship but with his ship safe and find them unharmed. The speaker thus values their safety and the safety of Charaxos over the material gains the addressee hopes for. ${ }^{40}$

Several scholars have commented on the unusual syntax of these lines, including the presence of two emphatic pronouns, cદ́ and $\varepsilon^{\prime \prime} \mu \varepsilon$, in lines 7-9 [3$5]{ }^{41}$ The sentence thus emphasizes the contrast between the speaker and the addressee rather than that between their actions. Joel Lidov (ch. 3) deduces from this that the pronouns must be the subjects of the two different sets of

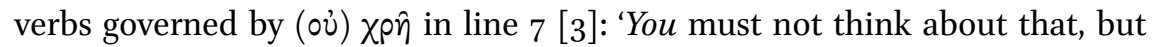
I must send and order to pray to Hera, etc.' This is possible, but I don't think it is necessary. The emphatic pronoun cé at the beginning of the sentence is intended foremost to draw a contrast with the preceding clause: 'Zeus and all the gods know this. You must not think about that ....' The emphatic है $\mu \varepsilon$ continues this train of thought: 'Zeus and all the gods know this. You must not think about that ..., but you must send and order me (to speak to the gods about this)'. It marks a contrast with the 'you', whether one takes it as subject or object of $\pi \dot{\varepsilon} \mu \pi \eta \nu$ xai $x \dot{\varepsilon} \lambda \varepsilon c \theta \alpha$ l. A problem with Lidov's interpretation is that $\pi \dot{\varepsilon} \mu \pi \eta \nu$

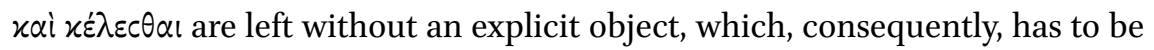
reconstructed from the context outside the poem. ${ }^{42}$ The construction with c⿱㇒㠯

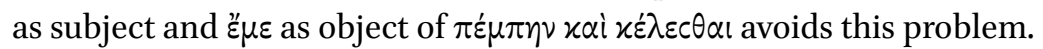

\footnotetext{
$38 \quad$ Rijksbaron (2002) 109.

39 Griffith, cited by Obbink (2015a) 3. Similarly Martin, this volume.

40 Cf. Nünlist (2014), Bierl, ch. 14, and Stehle, this volume.

41 See Bierl, ch. 14, Bowie, and Lidov, ch. 3, this volume.

42 Lidov suggests that Sappho commands a chorus which on her behalf can go and pray to Hera.
} 


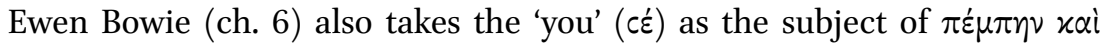
$\chi \varepsilon \dot{\varepsilon} \lambda \varepsilon c \theta \alpha$, but is troubled by the fact that these two infinitives, according to the standard interpretation, refer to the same action (directing the speaker to pray to Hera). He therefore proposes to emend है $\mu \varepsilon$ to $\varepsilon^{\prime} \mu \alpha$ and to postulate two different actions, thus translating: 'Don't you think of that, but both send my stuff and tell Charaxos to make supplications to queen Hera that he should arrive here

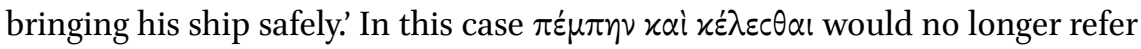
to one and the same action, but to two different ones with two different direct objects. This emendation creates other problems, however. Firstly, the name Charaxos (line 12 [8]) appears too late in the sentence to be taken as object with

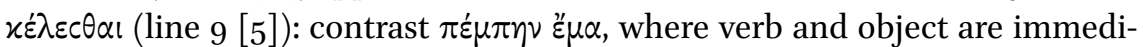
ateley juxtaposed. Secondly, Bowie has to postulate the absent Doricha as the addressee (she would be with Charaxos in Egypt, from where she can send Sappho's stuff and order Charaxos to pray to Hera for his safe return). This makes one wonder how we are to imagine the communication between speaker and addressee in this poem taking place. Finally, Bowie is correct that Iliad 6.269279, adduced by Lidov (ch. 3), is not a perfect parallel for the situation described in the Brothers Song, but it does distinguish the same two activities as being part of one act of supplication: Hector orders his mother Hecuba both to lead a procession to the temple of Athena and to vow twelve cows to her. I see no reason to abandon the standard interpretation of these lines, which makes the addressee the subject of $\pi \dot{\varepsilon} \mu \pi \eta \nu$ xai $x \dot{\varepsilon} \lambda \varepsilon c \theta \alpha$ and connects both verbs to the act of supplication which the speaker offers to perform on behalf of Charaxos.

The speaker says that she hopes that Charaxos, when he returns, finds

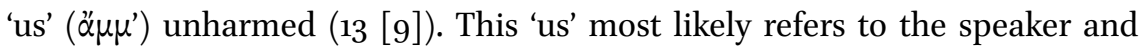
addressee, since no other persons, besides Charaxos, have been mentioned in the poem so far. In line 21 [17], the same 'us' are connected to the other brother, Larichos. The word which the speaker uses in line 13 [9] for being unharmed

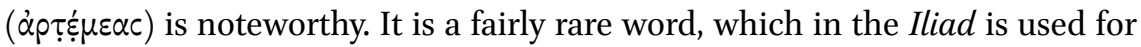
heroes who return from the battlefield unharmed ${ }^{43}$ It is another example of Sappho's use of martial and heroic language to describe her own, non-martial situation. ${ }^{44}$ But what does it refer to here? Does she use it in the physical sense of 'unharmed' or does it possibly refer to some political or economic troubles in which they find themselves? The 'storms' the speaker mentions in the next stanza could refer to the dangers Charaxos might encounter at

43 Hom. Il. 5.515 and 7.308. Nünlist (2014) adduces Od. 13.43, where the word is used in a slightly different sense, but also seems to refer to physical well-being. Stehle, this volume, argues for the meaning 'steadfast' or 'unshaken'. 
sea, but they could also point to the political troubles in which the speaker and addressee find themselves: Alcaeus often uses storms as metaphor for the political problems he encounters. ${ }^{45}$ In any case, speaker and addressee appear to be in trouble even before Charaxos returns. While the addressee is convinced that these troubles will be over once Charaxos returns with his laden ship, the speaker is not.

The speaker instead puts her trust in the gods. They can provide good weather after a storm, and Zeus, if he pleases, can send a daimon who can turn people away from their troubles and make them blessed and fortunate. While the meaning of lines $17^{-20}\left[13^{-16}\right]$ is clear, the syntax is not. One can take $\delta \alpha i \mu o v \alpha$ both as the subject and the object of the verb $\pi \varepsilon p \tau p o \dot{ } \pi \eta \nu,{ }^{46}$ which is the Aeolic aorist infinitive of Attic $\pi \varepsilon p ı \tau \rho \varepsilon \tilde{\tau} \omega$ ('to turn around'). The genitive of the relative pronoun $\tau \hat{\omega} \nu$ can be connected to $\delta \alpha i \mu o v \alpha$ ('their good spirit'), to $\pi \delta v^{\prime} \omega \nu$ ('their troubles'), or to ह่ $\pi \dot{\alpha} \rho \omega \gamma$ ov ('their helper'). I prefer to take it primarily with $\pi o ́ v \omega \nu$ and to make $\delta \alpha i \mu o v \alpha$ the subject of the verb $\pi \varepsilon \rho \tau \rho \dot{\sigma} \pi \eta \nu$, thus translating: 'Those from whose troubles the king of Olympus wishes that a daimon as helper turn (them) away, they are blessed and full of good fortune.'

The syntax remains somewhat strained and West has therefore proposed to

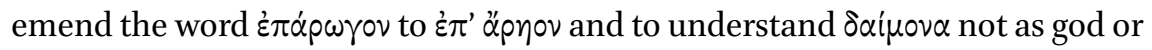
spirit but as 'fortune', translating: 'Those whose fortune the ruler of Olympus chooses to turn around from hardship to the better, they come out blessed and prosperous. ${ }^{47}$ I don't think the syntax is so convoluted that it warrants this emendation and a likely echo of this passage in Theocritus 17.123-132 makes it improbable. ${ }^{48}$ With $\delta \alpha^{\prime} \mu \circ v \alpha$ in the sense of 'good spirit', this stanza furthermore creates a nice parallel with the next one: Zeus, if he wishes, can send a divine helper, whose role, in the case of Sappho, is matched by Larichos, once he becomes a man. One can, in fact, notice a number of parallels between the last

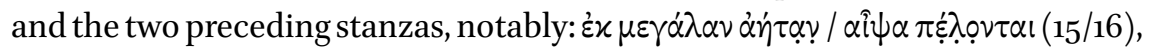

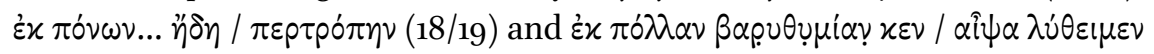
$(23 / 24)$.

The next question is the import of the word $\pi 0 \lambda v 0 \lambda \beta 0$ in line 20 [16]. It can mean 'very wealthy' or 'very happy, rich in blessings'. The one other occurrence of the word in the fragments of Sappho, fr. 133, where it is applied to Aphrodite, does not resolve the ambiguity. Campbell, following LSJ, translates the word here with 'rich in blessings', ${ }^{9}$ but a materialistic reading cannot be excluded

\footnotetext{
45 Page (1955) 179-197, Heirman (2012) 151-157.

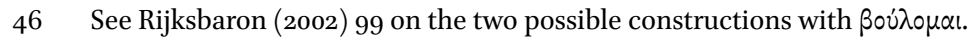

47 West (2014) 9. Similarly Ferrari (2014) 2-3.

48 Bierl, ch. 14, and Obbink, ch. 9, this volume, quoting Henrichs (forthcoming).

49 Campbell (1982a) 151.
} 


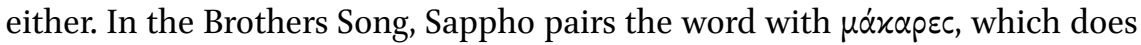
have a spiritual meaning ('happy, blessed'). It is unclear, however, if she wants to use $\pi 0 \lambda \dot{\nu} 0 \lambda \beta 0 \mathrm{l}$ as a synonym of $\mu \dot{\alpha} x \alpha \rho p \varepsilon c$ here to reinforce its meaning ('those whom Zeus helps are happy and blessed'), or as an added benefit ('happy and rich'). This is not without significance for the interpretation of the song. The speaker and addressee disagree, after all, as to what will bring them salvation: Charaxos' material goods or Hera's help and the blessings of the gods that keep them safe. It is possible that with the word $\pi 0 \lambda v 0 \lambda \beta 0$ o the speaker wants to suggest that, if they trust in the gods, they can have both: blessings ( $\mu \alpha \dot{x} x \alpha \rho \varepsilon c)$ and material riches ( $\pi \circ \lambda$ io $0 \lambda \beta 0 \iota) .{ }^{50}$ Both are probably relevant to the situation they find themselves in. The poem, in fact, works better if the outside audience, unlike the speaker and addressee in the poem, already assumes that Charaxos, when he comes back, will not return with a full ship, for example because they already know from other songs of Sappho that he squandered the family's fortune on a courtesan named Doricha. This would ensure that the audience understood the speaker's worries about Charaxos' chances of coming back with a loaded ship and great fortune, and that it sided with the speaker in the poem from the outset.

The last stanza of the poem contains further ambiguities. The first line of this stanza includes the expression 'if Larichos lifts his head', if this is what was originally in the poem, because the text of the papyrus actually reads: 'if Lari-

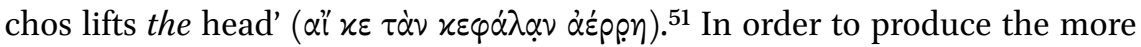
likely reading 'his head', it is necessary to emend the text to $F \dot{\alpha} \nu \varkappa \varepsilon \varphi \dot{\alpha} \lambda \alpha \nu \alpha$ á $\rho p \eta \eta$, now also accepted by Obbink. ${ }^{52}$ The use of the article as an unemphatic possessive pronoun, common in classical and later Greek, is otherwise not attested in the Lesbian poets, especially where 'words meaning parts of the person' are concerned, ${ }^{53}$ and $F$ is easily mistaken for $\tau$, especially when the result agrees with contemporary Greek idiom. According to Edgar Lobel's analysis of the use of the definite article in the Lesbian poets, if they want to say 'Larichos lifts his head', they use the word 'head' ( $\kappa \varepsilon \varphi \dot{\alpha} \lambda \alpha \nu)$ by itself, with the possessive pronoun ( $F \dot{\alpha} \nu \kappa \varepsilon \varphi \dot{\alpha} \lambda \alpha \nu)$, or with the possessive pronoun and an article ( $\left.\tau \dot{\alpha} \nu F^{\prime} \alpha \nu \kappa \varepsilon \varphi \dot{\alpha} \lambda \alpha \nu\right)$, but never with just the article $(\tau \dot{\alpha} \nu \kappa \varepsilon \varphi \dot{\alpha} \lambda \alpha \nu) .{ }^{54}$

5o This is the way Stehle, this volume, reads the line. Bierl, ch. 14, this volume, argues for a spiritual meaning, connected to the mysteries.

$5^{1} \quad$ This was first pointed out to me by Joel Lidov.

52 Obbink, Ch. 1, this volume.

53 Lobel (1927) lxxxii.

54 Idem, lxxxi-lxxxii. Lobel allows for one exception, when a word denoting a body-part is accompanied by a predicative adjective ( $\$ 26$, pp. xci-xcii), but this does not apply here. 


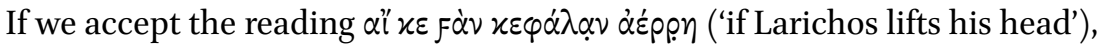
how is it meant: literally or figuratively? In Greek literature the expression is most often used literally, ${ }^{55}$ but it is hard to see what a literal meaning could signify here. Christopher Pelling and Maria Wyke have suggested that Larichos was perhaps dangerously ill and is asked to lift his head from his sickbed, ${ }^{56}$ but the problem with this interpretation is that we are never told about Larichos' sickness in the poem nor in the biographical tradition.

In some passages in Greek literature the expression 'raise your head up' can be understood metaphorically, for example in Euripides, Supp. 289, where Theseus seems to be asking his mother to control herself. A parallel has been drawn with the lifting of the head in boxing. ${ }^{57}$ Another passage that may be relevant to Sappho's use of the term, is Sophocles, oT 22-24, where the city is described as being unable to raise its head when drowning in a storm at sea. Is Larichos expected to 'lift up his head' to weather the 'storms' described in lines $15^{-16}$ ? In all these cases, in which the phrase is used metaphorically, the persons to whom it applies are asked to pick themselves up and to stand firm. This is probably what it means here too. A metaphorical reading of 'raising his head' is further suggested by the word $\beta \alpha \rho v \theta u \mu i \alpha$ in the third line of the strophe (23 [19]): The 'heavy-heartedness' the speaker and addressee currently suffer is 'lifted' by the raising of Larichos' head. ${ }^{58}$

The expression is coupled with the speaker's wish that Larichos in time become a man (22 [18]). Unfortunately this expression also allows for different

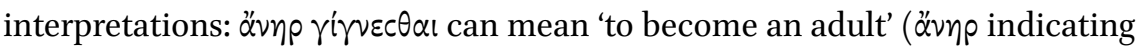
an age group), 'to become a gentleman' (a' $\nu$ p indicating a class) or 'to become a husband / get married' ('ँ $v \eta p$ denoting 'husband', as often in Sappho: e.g. fr. 16.7). What should it mean here? Probably, as Obbink argues, all of the above: '[Larichos] should become a man. Presumably this would include aristocratic demeanor, noble marriage, transfer of wealth, and production of legitimate off-

Neri (2015) $66 \mathrm{n}$. 97 defends the reading of the papyrus by arguing that the word is used here not in the sense of 'head' but in the metaphorical sense of 'life' or 'person', but also in the parallels he cites for this meaning from Homer and the tragedians it does not occur with the article alone (see my next note), nor is this to be expected, since metaphors follow the syntax of the vehicle, not the tenor.

E.g. Hom. Il. 10.80, Aes. Cho. 496, Eur. Hec. 500, Tro. 98-99. For more parallels see the commentary of Fries (2014) on Eur. Rh. 7 and 789 . The expression is used in these cases without the article or with article and possessive pronoun (Aes. Cho. 496).

$5^{6} \quad$ Pelling and Wyke (2014) 43.

57 Bierl, ch. 14, Lidov, ch. 3, and Obbink, ch. 9, this volume.

$5^{8}$ This was first suggested to me by Casper de Jonge. 
spring. ${ }^{59}$ Alternatively, it has been argued that Larichos is already an adult, but

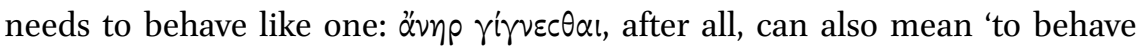
like a man, to be brave. ${ }^{60}$ The aorist aspect of the subjunctive argues against this interpretation, however. It indicates that Larichos is expected at a specific moment in the future to 'become a man' rather than to behave like one continuously. When Electra instructs Orestes to behave like a man in Euripides' Electra 694, she uses a present infinitive.

We know more about Larichos' situation from the biographical tradition. As we have seen above, Athenaeus reports that Sappho praised him for pouring the wine in the townhall of Mytilene, and a scholion to the Iliad adds that this

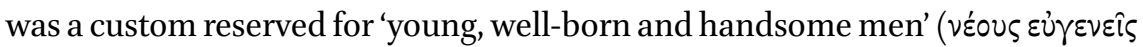
$\varepsilon \dot{\pi} \pi \varepsilon \pi \varepsilon \hat{\zeta}$ ). ${ }^{61}$ Whether one belonged to the 'well-born' elites or not, was for most aristocratic Greek families a contested matter: one had to be recognised as such. ${ }^{62}$ By being allowed to pour the wine in the townhall Larichos proves that he (and his family!) belong to the local elite. This in turn holds great promise for the future, because when Larichos grows up and becomes an adult, he can, as a result, marry into a good family, become a gentleman, etc. I believe that this is what the speaker hopes for when she wishes that Larichos lift up his head and become a man. Larichos' position as wine pourer in the townhall may have been spoken of in the missing strophe(s) at the beginning of the poem. ${ }^{63}$ Another way to gain access to the elite was by amassing wealth through 'risky long-distance maritime trade expeditions'.64 This is the strategy Charaxos appears to have adopted and in which the addressee puts his or her trust. ${ }^{65}$

Some interpreters assume that the speaker in this last strophe criticizes Larichos as being lazy (if this is what '[not] lifting his head' can mean) and not quick enough in proving himself a man. ${ }^{66}$ This depends in part on how $\delta \dot{\eta} \pi 0 \tau \varepsilon$ in line 23 [19] is to be understood: this combination of particles can express impatience ('finally'), but also a neutral attitude toward the progress of time ('in time'). ${ }^{67}$ I understand $\delta \dot{\eta} \pi \circ \tau \varepsilon$ here in this second way and read it as an

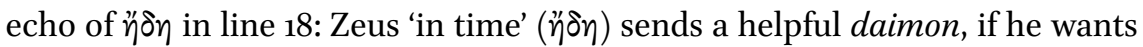

59 Obbink (2014b) 35 and ch. 9, this volume.

6o Martin, this volume.

61 Sappho test. 203, quoted above.

62 Wecowski (2014) 23-26 with earlier bibliography.

63 Cf. Obbink (2015a) and ch. 2, this volume.

64 Wecowski (2014) 24.

65 Cf. Raaflaub, this volume.

66 Martin and Stehle, this volume.

67 Denniston (1954) 213. 
to make people happy and blessed, and for us ( $\varkappa_{\alpha} \mu \mu \varepsilon c, 21$ [17]) good fortune will take the form of Larichos, when 'in time' ( $\delta \dot{\eta} \pi \circ \tau^{\prime}$ ) he becomes a man. A positive reading of these lines also agrees better with the ancient testimonia, which tell of Sappho praising Larichos and being fonder of him than of her older brothers. ${ }^{68}$

\section{Interpretation}

In order to understand this song of Sappho it is of primary importance to determine who Charaxos and Larichos are, what their relationship is to the speaker, and who the speaker and addressee are. The ancient tradition understood Charaxos, Larichos and the speaker to be brothers and sister. It must have based this idea on Sappho's poetry, and the extant fragments indeed contain some indications that this was the most likely nature of their relations. Fragment 5 is spoken by a sister to a brother who may be identified as Charaxos, if one accepts the pun on his name in line 6 of this poem (see above). ${ }^{69}$ This identification is strengthened by the fact that the situation of the brother in this poem is very similar to that of Charaxos in the Brothers Song: he is away with his ship at sea and expected to come home. In the Brothers Song the speaker offers to pray to Hera, while in fragment 5 she prays to the Nereids for his safe return. Charaxos thus appears to be the brother of the speaker in both songs. Charaxos' relationship with the speaker and addressee in the Brothers Song is implicitly compared to that of Larichos, who, according to the speaker, can provide for them in a way Charaxos does not. Therefore the ancients were probably right in understanding Charaxos, Larichos and the speaker as being brothers and sister.

One might add to this that the speaker in the Brothers Song is most likely a woman. The wording of the song does not reveal the gender of the speaker, but most speakers in Sappho's poems, when we can identify them, are women, and the situation in this poem, as we have seen, resembles that of fragment 5 , where the speaker is identified as a sister. Neither in this fragment nor in the Brothers

68 Test. 213a and 252, both quoted above.

$69 \operatorname{Lidov}($ ch. 3 ) argues that the speaker in fragment 5 does not have to be the sister, since she is spoken of in the third person (fr. 5.9), but if the speaker is not the sister mentioned in this line, he or she is never identified in the song and it would become very hard to understand. One then has to assume that (only) the performance context would have made clear who the 'brother', the 'sister' and the speaker were. This is not what we commonly find in Sappho's (extant) poetry. 
Song does the speaker explicitly identify herself as Sappho, however, the way the speaker does, for example, in Sappho fragments 1 or 94. This is significant, because it makes it easier for other women, besides Sappho, to perform these songs and so pretend to be the sister of Charaxos and Larichos. I believe that the speaker could be identified with Sappho, as the ancients apparently did, but other women could perform these songs and pretend to be the sister of Charaxos and Larichos as well. I will come back to this.

For now let us accept that Sappho is the speaker and Charaxos and Larichos are her brothers. Who then is the addressee? Obbink lists various possibilities: a concerned friend or family member, Charaxos' lover, the speaker's companions, or the speaker herself in a form of reflective self-address. ${ }^{70}$ Most scholars prefer the first option, namely a concerned friend or family member, and this seems to me, too, to be the best option. Obbink opts for the mother and has been followed in this by West, Franco Ferrari, Camillo Neri and Leslie Kurke. ${ }^{71}$ Both René Nünlist and Anja Bettenworth, however, have raised some reasonable objections against this idea, ${ }^{72}$ of which the most cogent is the absence of a reason why the mother would have to send Sappho to pray to Hera rather than do this herself. It has been suggested that she is too old, ${ }^{73}$ but this is not mentioned as a reason in the poem, and if Larichos is her son and not yet a man, she cannot be very old.

I believe that the addressee is a man and that Sappho proposes that he send her to go to pray to Hera, because this is something she can do better than he. Neri objects that this man could have taken over the role of Charaxos and provided for Sappho the way she now hopes Larichos will do, ${ }^{74}$ but this reasoning assumes that the addressee is able and willing to do this. She may be implicitly criticizing him for doing nothing except 'babbling' and relying on the fortunes of Charaxos instead. In this exchange a subtle gender opposition might be detected, not unlike that found in other Sapphic songs, notably fragment

70 Obbink (2014b) 41. For a complete list of possibilities suggested till now, see Neri (2015) $5^{8-59 .}$

West (2014) 8, Ferrari (2014) 4, Neri (2015) 6o, Kurke, this volume. The supplement Obbink proposes (ch. 9), following a hesitant suggestion of West, in line 4 ( $c^{\varepsilon}, \mu \hat{\alpha}[\tau \varepsilon \rho)$ to support his claim that the person addressed is Sappho's mother, is far from certain. As West remarks, there is very little space before these letters to fit two more syllables, which the metre would require (West [2014] 9), but see Obbink's defence of the possibility in ch. 9, this volume.

72 Nünlist (2014), Bettensworth (2014). Cf. Bierl, ch. 14, this volume.

73 Hammersteadt, quoted by Obbink (2014b) 41.

$74 \quad$ Neri (2015) 59 . 
$16 .{ }^{75}$ While the male interlocutor makes the economical argument that all their problems are solved if Charaxos delivers the goods, the female counters that trust in the gods and the good reputation of Larichos count for more. ${ }^{76}$

If we accept that the addressee is male and most likely a family member of Sappho, Charaxos and Larichos, there are three possibilities:

1) The adressee is Sappho's father

2) The addressee is Sappho's husband

3) The adressee is Sappho's third brother, Erigyios. ${ }^{77}$

Sappho's father can be excluded. Ovid in his Heroides informs us that Sappho's father died when she was six years old. ${ }^{78}$ We do not know, of course, if Ovid or his source did not make up this detail, but if there was a poem preserved in Book 1 of Sappho in which an (almost) adult Sappho speaks to her father, it is unlikely that someone would have invented this detail. I think we can exclude Sappho's husband as well. He is a problematic character in Sappho's biography any way, ${ }^{79}$ and it would be odd if he had to rely on Sappho's brothers, including the young Larichos, for his fortune and fame. This leaves the third brother, who in the ancient biography I quoted above is called Erigyios, but in other sources Eurygios. ${ }^{80} \mathrm{I}$ am surprised that in the discussion about the identity of the addressee in this poem so far, this option has not been considered, because he seems to be the most obvious candidate. ${ }^{81}$ With Sappho's father dead and Charaxos, who was the oldest brother (test. 252), away at sea, Eurygios would be the kurios of Sappho, her mother and her younger brother, Larichos, according to Greek family custom. ${ }^{82}$ As Sappho's kurios, he would have the proper

75 See also Stehle and Bierl, ch. 14, in this volume.

76 On the association of men with economic affairs and women with religion and concern for the reputation of the family in ancient Greece, see, for example, Vernant (1963).

77 Bierl, ch. 14, this volume, mentions a fourth possibility, namely that the addressee is Sappho's uncle, but he is never mentioned in the testimonia of Sappho, which would be surprising, if he played a prominent role in one or more of her songs. The same objection holds for Bettenworth's suggestion (2014) that the addressee is Sappho's nurse.

78 Ovid, Her. 15.61-62 (= test. 13 Campbell). Cf. Obbink, ch. 9, this volume.

79 Parker (1993) 309.

80 Test. 253 (Suda). For a defence of the name Eurygyios, see Caciagli, this volume.

81 I already made this suggestion in Lardinois (2014) 191. See now also Caciagli, this volume.

82 Blundell (1995) 114. Unless we are supposed to imagine Sappho as already being married at the time when this poem is set, in which case her husband would be her kurios. Since her brother Larichos is still a young man in the poem, we are made to think that the speaker is not very old either. Cf. Ferrari (2014) 1 and Obbink (2015a) 3 . 
authority to order Sappho to pray to Hera on behalf of their brother, while being at the same time close enough to Sappho in age and social position for her to address him the way she does in the opening lines of the fragment. ${ }^{83} \mathrm{His}$ name must have been mentioned somewhere in Sappho's poetry to have made it into the biographical tradition and the Brothers Song is as good candidate as any poem. He was probably identified as the addressee in the lost opening stanza(s).

Now that we have postulated who Charaxos, Larichos, the speaker and the addressee are, we should ask ourselves if we are supposed to believe that these were Sappho's real brothers or whether we are to take them instead as fictional characters. We should not forget that there were more songs about Sappho and her brother besides the Brothers Song. Such a collection of songs about the poet and a series of characters is quite unique. The only parallel in archaic Greek poetry I can think of are the songs Archilochus composed about his dealings with Lykambes and his daughters. Archilochus criticizes and makes fun of them in a series of poems, including the famous Cologne epode. ${ }^{84}$ The Brothers Song resembles this epode in its use of an extensive dialogue between a first person speaker and his or her addressee. ${ }^{85}$

In the case of Archilochus three scenarios have been proposed with respect to the identity of Lykambes and his two daughters. They were either 1) fictionalised characters, but based on real-life persons who were known to the original audience, 2) purely fictional characters, or 3 ) cultic figures. ${ }^{86}$ There is no consensus yet on which of these scenarios fits Archilochus' poetry best, and our findings about Sappho's songs about her brothers could throw new light on Archilochus' poems about Lykambes and his daughters too.

The Brothers Song does seem to refer to the cult of Hera at the ancient site of Messon, ${ }^{87}$ but nothing in the song warrants us to believe that it was actually performed there. The names of Charaxos and Larichos can be given

83 There is a tradition in Greek literature of sisters lecturing brothers: see Peponi, this volume. The poem in which, according to Herodotus, Sappho 'heavily criticized' ( $\propto \tau \varepsilon \varepsilon \varkappa \varepsilon \tau \tau o ́ \mu \eta \sigma \varepsilon)$ her brother Charaxos (Hdt. 2.135), would fit this tradition.

84 Archilochus fr. 196a. For a discussion of the sources about Lykambes and his daughters, see Kivilo (2010) 104-106.

85 Martin, this volume, draws a parallel between the Brothers Song and Archilochus fr. 196a as well.

86 Fictionalised real persons: Carey (1986), Slings (1990); purely fictional characters: Henderson (1976); cultic figures: West (1974).

87 See Pirenne-Delforge \& Pironti (2014); also Bierl, ch. 14, Boedeker, Caciagli, Lidov, ch. 3, Nagy, and Obbink, ch. 9, in this volume. 
cultic significance, ${ }^{88}$ but this is true of almost any Greek name. One could point to the figure of Phaon as another example of a cultic figure who later became attached to the ancient biography of Sappho: he was a local variant of the god Adonis, but by the fourth century BCE he was known as Sappho's lover. ${ }^{89}$ In this case, however, there is external evidence that Phaon was a cultic figure on Lesbos (test. 211), while in the case of Sappho's brothers there is none. Some of the details of their story also argue against such a cultic status, such as the fact that Larichos was said to have served the wine in the townhall of Mytilene.

I consider it very likely, however, that the two brothers were fictional characters. For one thing, they never seem to change or to grow up. It is of course tricky to argue from silence, when so much of the work of a poet is lost, but it is striking that when Charaxos is mentioned in the extant poetry of Sappho or in the biographical tradition, it is always in connection with his absence from home and his affair with Doricha. We do not hear if he later settled down (or not), got a wife and children, etc. Similarly, Sappho 'often' praised Larichos for serving the wine in the townhall of Mytilene, according to Athenaeus, but neither in the biographical tradition nor in the extant fragments of Sappho do we hear anything else about him. He seems to be frozen in this state of being a "Ganymede". This is more suggestive of fictional characters than of real persons whom Sappho had the occasion to sing about in the course of her and their lives.

If Charaxos was Sappho's real brother, it is difficult to understand why she would publicly scold him in her poetry, as Herodotus reports and fragment 15 seems to suggest. It would be an extreme case of airing the family's dirty laundry and Sappho herself would contribute to the bad reputation of the family she expresses concern about in fragment 5 and in the Brothers Song. This circumstance constitutes an important difference with the songs of Archilochus about Lycambes and his family, because Archilochus supposedly shamed them deliberately with his poems. If one wishes to maintain that Charaxos was Sappho's real brother, one has to postulate a performance situation in which such a critical stance toward a real brother would be permissible and accepted. One can think of an intimate, family gathering, but why would Sappho compose a song for such an occasion? At a family get-together she could scold her brother just as well in regular speech. While composing songs about her brothers, she must have known that they would circulate beyond the family circle at some point, as they ultimately did. Such is the nature of songs.

88 See Bierl, ch. 14, Lidov, ch. 3, and Obbink, ch. 9, in this volume.

89 Bowra (1961) 212-214, Nagy (1973). 
Another possible scenario is the songs' performance at wedding banquets or women's festivals. There is some evidence that Greek women sang songs at wedding banquets in which they mocked men: traces of such songs are preserved among the fragments of Sappho. ${ }^{90}$ Similarly at some women's festivals, such as the Thesmophoria in Athens, women made fun of men, both real and fictional. ${ }^{91}$ But the Brothers Song, like the other songs about Sappho's brothers, such as fragment 5 , lacks the light-hearted character of those comic compositions (pace Wright 2015). All in all it seems more likely that Charaxos, Larichos and Eurygios were fictional characters rather than Sappho's real-life brothers.

The difference between fictional and real, historical brothers may ultimately not be so great, however, for even real-life persons are necessarily abstracted and fictionalised in the process of composing a song. For if Sappho's songs about her brothers or Archilochus' compositions about Lycambes and his daughters were based on real-life persons, we should ask ourselves the question why ancient audiences would be interested in listening to such songs about the personal vicissitudes of these poets? It must be because these poets generalize from their own experiences. As Chris Carey, who believes that Lycambes and his daughters were based on real persons, puts it:

As a general rule, the archaic solo poet uses his own person and represents the events he narrates or judges as belonging to his own life or the lives of those around him. But though he writes about himself he usually sees two aspects to his experience, the individual and the general. It is as a rule true that the archaic monodists use their own experience to express a truth of general validity. The poet rarely concentrates upon the details of his life; he seeks rather to use his own experience to inform others. ${ }^{92}$

This has consequences for the other songs of Sappho as well, such as her love songs about Atthis, Anactoria and the other women. We probably should not interpret these as personal declarations of love, but rather as general reflections about the vicissitudes of love and the erotic appeal of young women. ${ }^{93}$

9o Lardinois in Lardinois \& Rayor (2014) 135. See Sappho frs. 110, 121 and 138.

91 O'Higgins (2001) and (2003) esp. 15-36.

92 Carey (1986) 67. See also Bakker (1998), Calame (2005) 5; and on Sappho in the Brothers Song: Nagy, Peponi, and Stehle in this volume.

93 I still believe that most of the women whom Sappho sings about in her songs, such as Atthis and Anactoria, are young women of marriageable age: Lardinois (1994) contra Parker (1993), Stehle (1997) esp. 263-311, and Schlesier (2013). See also Bierl, ch. 14, this volume. 
Similarly, even if Charaxos, Larichos and Eurygios were Sappho's real brothers, the songs she sang about them would address the concerns of any sister confronted with irresponsible older brothers or promising younger ones. This general applicability would make these songs suitable for (re)performances by other women, including performances at cultic festivals, such as the cult of Hera at Messon, or other public venues, such as wedding banquets, just as much as songs about stock characters or legendary figures. I still consider it more likely that Charaxos, Larichos and Eurygios were recognised by Sappho's original audience as fictional characters, for the reasons I stated above, but if they are based on real brothers of Sappho, the meaning of these song would not necessarily be very different.

What then is the meaning of these songs? In my opinion they served as exempla that address a number of anxieties that haunted aristocratic Greek families: the loss of family capital and reputation, the risks of trading at sea, the allure of foreign courtesans, and strife between family members. Some of these themes are reminiscent of Hesiod's Works \& Days, such as the quarrel with a bad brother or the risk of trading at sea; others of Theognis, such as the loss of family capital and reputation. These are themes that transcend Sappho, her family and Lesbos and made these songs interesting for future generations of Greek listeners and readers too, which is why we can still find them in the sands of the Egyptian desert today.

\section{Conclusion}

In this paper I have argued for the authenticity of the Brothers Song in the sense that I believe that it was composed in Lesbos in the 6th century BCE. I have examined the biographical tradition about Sappho and her brothers and argued that there were more songs about these brothers among the poetry of Sappho, including fragments 5, 9 and 15 . The Brothers Song is not unique in this respect. I have analysed the text of this song in some detail and discussed some of its syntactical and idiomatic problems.

Finally, I have presented my interpretation of the song. I have argued that Charaxos, Larichos and the speaker should be considered brothers and sister and that the addressee is most likely the person who in the biographical tradition is identified as Sappho's third brother, Eurygios. I further have argued that these figures were probably fictional characters. The songs about these brothers address themes that are familiar from other archaic Greek poets as well. Sappho, however, manages to render these themes in a poetic style that is unique to her and that makes us believe her characters are real. 